\title{
Sistem Akuaponik "Kulkas Hidup" Untuk Daerah Lahan Terbatas, Sulit Air dan Daerah Pasca Bencana
}

\section{Aquaponic System "KULKAS HIDUP” For Limited Land, Water Shortage Areas and Post Disaster Area}

\author{
Juli Nursandi*1, dan Tulas Aprilia ${ }^{2}$ \\ ${ }^{1}$ Prodi Budidaya Perikanan, Jurusan Peternakan, Politeknik Negeri Lampung \\ Jl. Soekarno Hatta No. 10 Rajabasa, Bandar Lampung, 35144, Indonesia \\ ${ }^{2}$ Prodi Teknologi Pembenihan Ikan, Jurusan Peternakan, Politeknik Negeri Lampung \\ Jl. Soekarno Hatta No. 10 Rajabasa, Bandar Lampung, 35144, Indonesia \\ *E-mail: julinursandi@polinela.ac.id
}

\begin{abstract}
ABSTRAK
Tingginya pertumbuhan jumlah penduduk menyebabkan semakin berkurangnya lahan pertanian dan perikanan, sementara di sisi lain permintaan akan bahan pangan semakin meningkat. Hal ini mendorong munculnya inovasi menciptakan budidaya pada lahan terbatas. Tujuan penelitian ini adalah untuk mengetahui survival rate ikan, laju pertumbuhan harian, feed convertion ratio, karakter media akuaponik, produktivitas sayuran serta kualitas air pada sistem akuaponik sebagai bentuk inovasi kulkas hidup. Penelitian ini diharapkan mampu menjadi solusi atas permasalahan pangan di daerah sempit, padat penduduk, daerah sulit air dan daerah pasca bencana. Hasil yang didapatkan Survival Rate pada kepadatan ikan $5 \mathrm{~kg} / \mathrm{ember}$ cukup baik yaitu $77-81 \%$. Laju pertumbuhan bobot harian serta feed convertion ratio pada kepadatan ikan $5 \mathrm{~kg} / \mathrm{ember}$ dengan frekuensi pakan satu kali lebih efektif dan menguntungkan. Karakter media akuaponik sistem kulkas hidup mempunyai banyak kelebihan yaitu: hemat air, sistemnya sederhana, tidak membutuhkan listrik, cocok untuk daerah minim lahan, biaya investasi murah, mudah di laksanakan, cocok untuk produksi rumah tangga, kepadatan ikan yang dipelihara cukup tinggi. Produktivitas sayuran kangkung juga baik dengan media tanam cukup menggunakan arang kayu, kepadatan tanaman cukup tinggi, dan jumlah pakan ikan yang rendah sudah mampu menghasilkan kangkung yang banyak dengan kualitas air yang cukup baik. Akuaponik sistem kulkas hidup dapat dijadikan pilihan solusi untuk ketersediaan pangan di daerah yang padat penduduk, daerah sulit air dan daerah pasca bencana.

Kata kunci: Akuaponik, Kulkas hidup, Pangan, Pasca Bencana
\end{abstract}

\section{PENDAHULUAN}

Tingginya pertumbuhan jumlah penduduk berdampak pada semakin berkurangnya lahan untuk pertanian dan perikanan. Hal ini dikarenakan lahan pertanian dan perikanan beralih fungsi menjadi pemukiman dan sentra usaha. Akuaponik menjadi salah satu sistem pertanian yang sangat penting di dunia dan dapat menjawab masalah berkurangnya lahan pertanian (Chakravartty et al., 2017). Di sisi lain, kebutuhan bahan pangan baik berupa protein hewani dan sayuran terus meningkat seiring bertambahnya jumlah penduduk. Kebutuhan bahan pangan dalam hal ini ikan dan sayuran biasanya dipenuhi dengan cara membeli di pasar. Salah satu upaya untuk memproduksi pangan di daerah perkotaan yang padat penduduk dan minim lahan yaitu sistem pertanian perkotaan dengan cara memanfaatkan keterbatasan lahan dan air untuk dapat tetap menghasilkan bahan pangan. Menurut Gosh \& Chowdhury (2019), akuaponik menjadi salah satu teknik pertanian yang berkelanjutan, berpotensi sebagai solusi untuk menyediakan makanan secara lokal dari rumah. Pada daerah yang terdampak 
bencana seperti banjir, longsor, gempa bumi dan angin ribut bahan pangan juga menjadi masalah yang serius. Bencana alam dapat mempengaruhi sektor pertanian, transportasi, perdagangan, industry pariwisata dan bidang lain (Wiwaha et al., 2018).

Sistem akuaponik skala kecil dicirikan dengan pemanfaatan luasan produksi yang kecil dan akan berpengaruh pada biaya pembuatan dan pengguna teknologi akuaponik (Palm, et al., 2018). Menurut (Wongkiew, Hu, Chandran, Lee, \& Khanal, 2017) sistem akuaponik mampu memproduksi unsur hara untuk kebutuhan tanaman. Umumnya Akuaponik yang di lakukan adalah dengan cara memelihara ikan dan sayuran dari ukuran kecil berupa bibit atau benih. Belum ada sistem akuaponik yang memelihara ikan dan sayuran dengan ukuran yang sudah besar, sehingga waktu panen ikan dan sayuran menjadi singkat dengan kualitas baik segar dan sehat. Metode akuaponik berpotensi menjadikan model / pola produksi sekaligus pola menyimpan pangan berupa ikan dan sayuran dalam keadaan hidup / segar untuk kebutuhan rumah tangga.

Menurut (Nursandi, 2018), ikan lele mampu dibesarkan ataupun disimpan dalam media ember 60 liter dengan dengan kepadatan 60-100 ekor. Pemeliharaan ikan dalam ember (budikdamber) dapat dimulai dari ikan yang berukuran kecil maupun ikan yang sudah besar. Jika pemeliharaan ikan dan sayuran dimulai dari ukuran yang sudah besar tentu saja waktu panennya lebih cepat. Budikdamber di desain dengan cara menanaman sayuran kangkung di atas media ember yang di dalamnya dipelihara ikan. Desain akuaponik yang baik adalah mengikuti prinsip keseimbangan ekologi (Forchinoa, Gennotte, Maiolo, Mélard, \& Pastres, 2018).

Budidaya ikan dan sayuran dengan sistem Akuaponik harus dirancang untuk dapat memenuhi kebutuhan konsumsi masyarakat secara kualitas maupun kuantitas. Oleh karena itu perlu dilakukan penelitian tentang pemeliharaan ikan lele dan sayuran kangkung berukuran besar, untuk dimasukkan ke dalam sistem akuaponik. Hal itu diharapkan akan dapat mempersingkat waktu tunggu produksi ikan dan sayuran, menjaga agar tetap segar dan sehat yang dapat diterapkan untuk daerah lahan sempit / padat penduduk, daerah sulit air, serta daerah pasca bencana. Tujuan penelitian ini adalah untuk mengetahui Survival Rate, Laju Pertumbuhan Harian, Feed Convertion Rate, Karakter media akuaponik, Produktivitas Sayuran serta Kualitas air pada akuaponik kulkas hidup.

\section{METODE}

Penelitian dilaksanakan selama 60 hari bertempat di Perumahan Tanjung Raya Permai, kecamatan Tanjung Senang Bandar Lampung. Alat dan bahan yang digunakan dalam penelitian ini adalah ember 80 liter, ikan lele ukuran 80-100 gram, pakan pellet 78 (merk hiprovite), penggaris, timbangan digital serta alat teskit kualitas air.

Penelitian ini terdiri dari 2 faktor perlakuan dengan 3 ulangan untuk masing-masing faktor. Faktor pertama yaitu perlakuan biomassa ikan di ember (3, 4, dan $5 \mathrm{~kg} / \mathrm{ember})$. Faktor kedua yaitu pemberian pakan ikan (1 kali dan 2 kali pemberin pakan per hari). Menggunakan rancangan acak lengkap (RAL) dengan selang kepercayaan 95\%. Rancangan dianalisis menggunakan software SPSS. Hasil berbeda nyata akan dilakukan uji lanjut menggunakan uji Duncan.

Wadah yang digunakan untuk pemeliharaan ikan lele adalah ember berkapasitas 80 liter sebanyak 18 unit yang diisi air masing-masing sebanyak 60 liter. Tahap persiapan wadah meliputi pencucian ember, pengeringan ember, dan pengisisan air. Setiap ember dicuci bersih kemudian dikeringkan dan diisi air. Pada masing-masing ember tidak diberikan aerasi. Ikan yang digunakan dalam penelitian ini adalah ikan lele ukuran konsumi yang berasal dari Jatimas Fish Farm, Bandar Lampung. Bobot ratarata ikan uji $8,5 \pm 10$ gram dan panjang rata-rata $18 \pm 2 \mathrm{~cm}$.

Penebaran benih dilakukan setelah diendapkan selama 2 hari untuk menghilangkan gas racun yang dapat terlarut dalam air. Sebelum ditebar dilakukan pengambilan data bobot dan panjang ikan tiap ember untuk mengetahui ukuran awal penebaran. Sesuai dengan rancangan percobaan, jumlah benih yang ditebar pada wadah pemeliharaan adalah untuk perlakuan $3 \mathrm{~kg} / \mathrm{ember}$ sebanyak \pm 30 ekor/ember, perlakuan $4 \mathrm{~kg} / \mathrm{ember}$ sebanyak \pm 40 ekor/ember, dan perlakuan $5 \mathrm{~kg} / \mathrm{ember}$ sebanyak 50 ekor/ember. 
Nursandi dan Aprilia : Sistem Akuaponik “Kulkas Hidup” Untuk Daerah Lahan Terbatas, Sulit Air...

Selama penelitian, pakan yang digunakan untuk perlakuan pemberian pakan adalah pakan buatan dengan merk dagang Hi-Pro-Vite 781 yang merupakan produk dari PT. Central Pangan Pertiwi. Pakan diberikan yaitu dengan perlakuan 1 kali dan 2 kali sehari. Perlakuan 1 kali pemberian pakan yaitu sore hari, perlakuan 2 kali pemberian pakan dilakukan pagi dan sore hari secara ad satiation (sekenyangnya). Sebelum diberikan pakan, pakan ditimbang terlebih dahulu, setelah diberikan, pakan yang tersisa ditimbang kembali.

Penyiponan kotoran dasar ember dan penambahan air maksimal $25 \%$ dari total volume air pemeliharaan. Kegiatan tersebut dilakukan ketika kualitas air sudah memburuk. Air yang digunakan untuk pergantian air adalah air yang telah diendapkan dan diaerasi pada tandon. Kotoran pada dasar ember dibersihkan dengan cara disedot menggunakan selang. Setelah itu dilakukan pembuangan air dengan selang sampai volume yang diinginkan kemudian dilakukan pengisian air yang berasal dari tandon. Untuk mengetahui parameter kualitas air dilakukan pengukuran seminggu sekali, yang meliputi parameter suhu, oksigen terlarut (DO), $\mathrm{pH}$ dan total amoniak.

Parameter pengamatan yang digunakan dalam penelitian ini adalah derajat kelangsungan hidup, laju pertumbuhan bobot harian, dan rasio konversi pakan

Derajat Kelangsungan Hidup (SR). Derajat kelangsungan hidup (Survival Rate) adalah perbandingan jumlah ikan yang hidup hingga akhir pemeliharaan dengan jumlah ikan pada awal pemeliharaan. Pada penelitian ini, data SR dihitung dengan menggunakan rumus dari Goddard (1996) :

$$
S R=\left(\frac{N_{t}}{N_{0}}\right) \times 100 \% \quad \begin{aligned}
& \text { Keterangan : } \\
& \text { SR = Survival Rate } / \text { kelangsungan hidup } \\
& \text { Nt = Jumlah ikan di akhir pemeliharaan (ekor) } \\
& \text { N0 = Jumlah ikan di awal pemeliharaan (ekor) }
\end{aligned}
$$

Laju Pertumbuhan bobot harian (LPH). Laju pertumbuhan bobot (\%) ditentukan berdasarkan selisih bobot rata- rata akhir (wt) dengan bobot rata-rata awal (wo) pemeliharaan dan dibandingkan dengan waktu pemeliharaan dengan rumus dari Huisman (1987) :

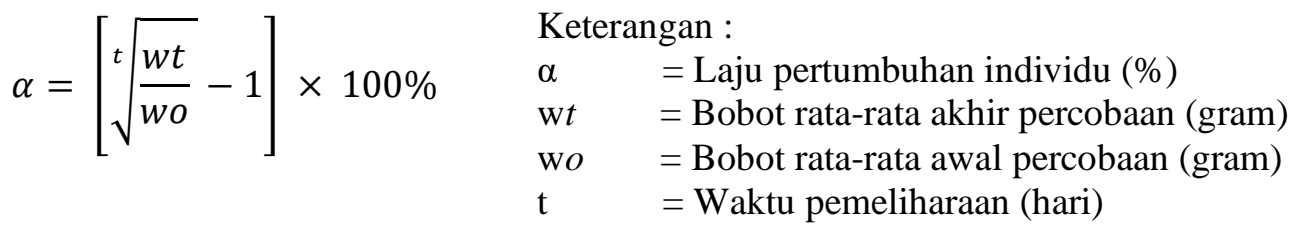

Rasio Konversi Pakan (FCR). FCR (feed conversion ratio) merupakan pengukuran kualitas pakan yang dilakukan dengan membandingkan jumlah pakan yang diberikan dengan pertambahan berat ikan yang dihasilkan selama pemeliharaan. Untuk menghitung FCR digunakan rumus Effendi (1997):

$$
\begin{array}{ll}
F C R=\frac{F}{(W t+W d)-W o} & \text { Keterangan : } \\
& \mathrm{FCR}=\text { Feed Conversion Ratio } \\
\mathrm{Wt}=\text { Biomassa akhir (gram) } \\
\mathrm{Wd} \text { = Biomassa total ikan mati (gram) } \\
\mathrm{W} 0 \text { = Biomassa total awal (gram) } \\
\mathrm{F} \quad=\text { Jumlah total pakan selama pemeliharaan (gram) }
\end{array}
$$

\section{HASIL DAN PEMBAHASAN}

Berdasarkan hasil uji statistik menggunakan SPPS 17 nilai SR yang didapat memberikan pengaruh yang berbeda nyata pada faktor pertama yaitu faktor biomassa. Faktor biomassa $4 \mathrm{~kg} / \mathrm{ember}$ sebesar $78-80 \%$ dan $5 \mathrm{~kg} / \mathrm{ember}$ sebesar $77-81 \%$ berbeda nyata dengan biomassa $3 \mathrm{~kg} / \mathrm{ember}$ yaitu sebesar $42-68 \%$. Hasil pengamatan pemeliharaan dan penyimpanan ikan di kulkas hidup selama 42 hari mendapatkan SR seperti pada Gambar 1. 


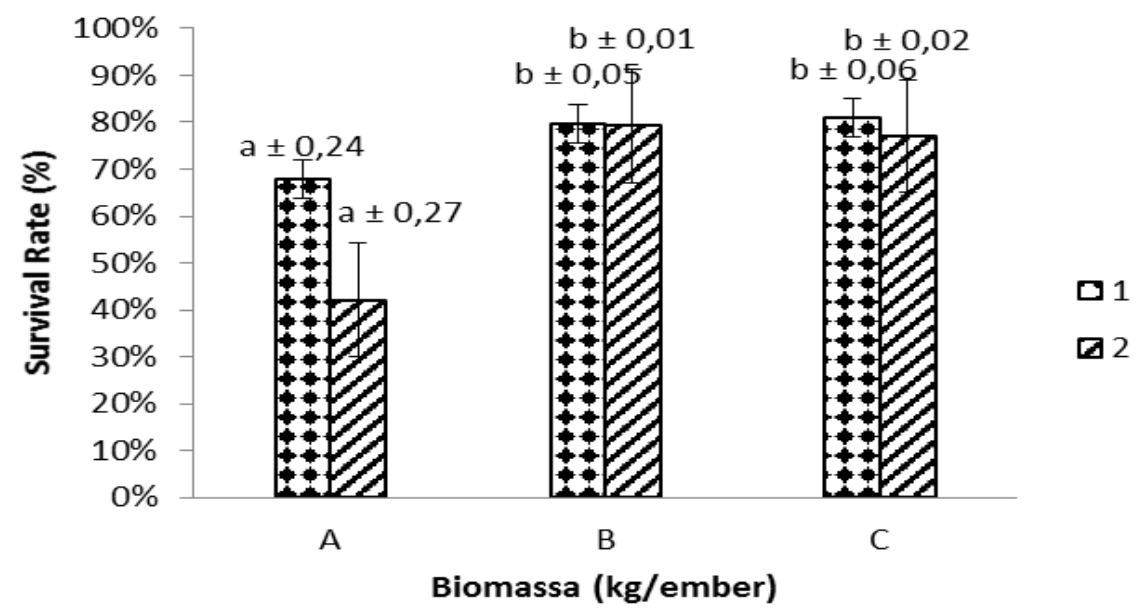

Gambar 1. Derajat Kelangsungan Hidup

Derajat Kelangsungan hidup pada kepadatan ikan $3 \mathrm{~kg} /$ ember secara teori harusnya lebih tinggi bila dibandingkan dengan kepadatan ikan 4 dan $5 \mathrm{~kg} / \mathrm{ember}$. Kematian ikan yang terjadi pada ember dengan kepadatan $3 \mathrm{~kg} / \mathrm{ember}$ diduga karena kesehatan ikan yang rendah dan ikan yang sudah lemas ketika ikan dibeli dari pengepul ikan. Menurut Nursandi (2018) SR ikan yang dipelihara selama 40 hari dengan ukuran panjang 12-14 cm pada budidaya ikan dalam ember (budikdamber) adalah rata-rata 60,42 persen.

Perlakukan pemberian pakan dengan frekuensi satu kali ataupun dua kali per hari tidak memberikan pengaruh yang berbeda pada kelangsungan hidup ikan. Sehingga pemberian pakan ikan sebanyak satu kali sehari lebih baik untuk pemeliharaan ikan akuaponik kulkas hidup.

Menurut Wicaksana (2015) kelulushidupan ikan lele di kolam akuaponik lebih tinggi dibandingkan dengan sistem konvensional tanpa akuaponik. Kualitas air memegang peranan penting terutama dalam kegiatan budidaya. Penurunan mutu air dapat mengakibatkan kematian, pertumbuhan terhambat, timbulnya hama penyakit, dan pengurangan rasio konversi pakan.

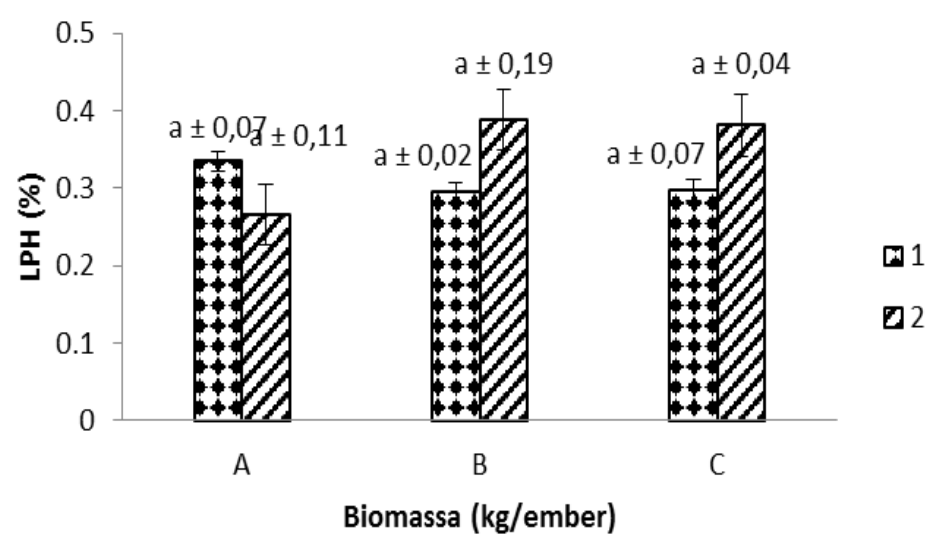

Gambar 2. Laju Pertumbuhan Harian

Kebutuhan pangan di wilayah perkotaan meningkat seiring dengan pertambahan jumlah penduduknya. Sedangkan produksi hasil pertanian semakin rendah karena lahan pertanian yang semakin sempit, makin sedikitnya tenaga kerja di bidang pertanian, dan tingginya biaya produksi dengan output rendah. Pemanfaatan lahan terbatas terutama pekarangan rumah terus diupayakan untuk memenuhi kebutuhan pangan keluarga. Model akuaponik mini ini mengintegrasikan budidaya ikan dan sayuran sekaligus pada lahan yang terbatas. Teknologi akuaponik lebih menguntungkan dibandingkan dengan teknik budidaya konvensional (Rokhmah, 2014). Budidaya ikan sistem akuaponik pada prinsipnya 
menghemat penggunaan lahan dan meningkatkan efisiensi pemanfaatan hara dari sisa pakan dan metabolisme ikan. Sistem ini merupakan budidaya ikan yang ramah lingkungan. (Setijaningsih, 2015).

Laju Pertumbuhan Bobot Harian ikan lele selama 42 hari dibudidayakan dalam ember dapat dilihat pada Gambar 2. Laju Pertumbuhan Harian Ikan lele antar perlakukan bobot dan frekuensi pemberian pakan tidak berbeda nyata.Kepadatan ikan lele $5 \mathrm{~kg} / \mathrm{ember}$ dengan frekuensi pemberian pakan satu kali sehari menjadi pilihan yang tepat untuk memelihara dan menyimpan ikan di daerah sempit / lahan terbatas, sulit air dan daerah pasca bencana. Laju pertumbuhan ikan lele pada kepadatan ikan $5 \mathrm{~kg} / \mathrm{ember}$ adalah 0,3-0,4\%. Laju pertumbuhan harian ikan dipengaruhi oleh umur ikan, semakin tua umur ikan maka laju pertumbuhannya akan semakin melambat. Menurut Kesuma dkk (2019), LPH ikan lele yang dibudidayakan dengan penambahan probiotik sebanyak $6 \mathrm{ml}$ sebesar 5,15\%.

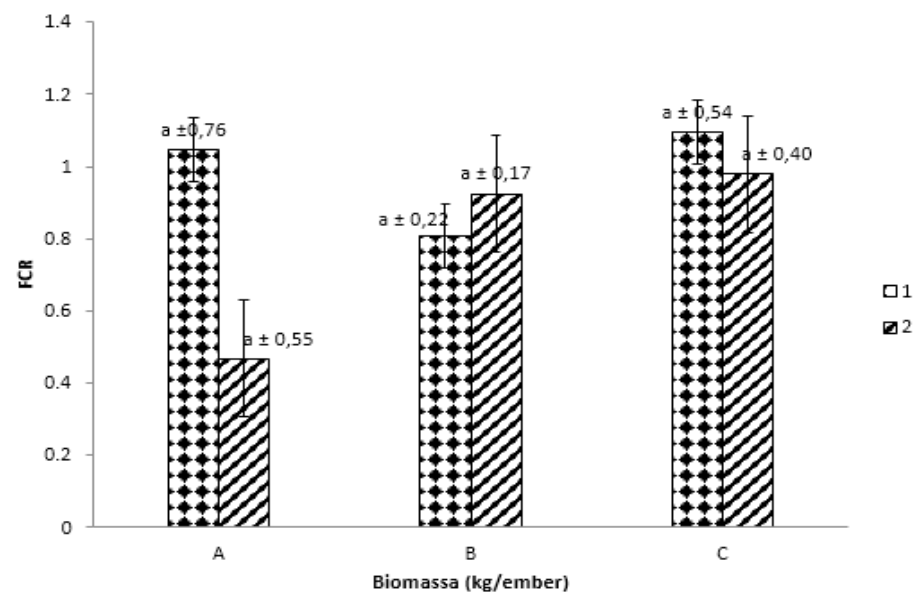

Gambar 3. Grafik Rasio Konversi Pakan

Hasil perhitungan rasio konversi pakan pada faktor biomassa juga menunjukan hasil yang tidak berbeda nyata. Nilai FCR selama budidaya dapat dilihat pada Gambar 3. Rasio konversi pakan ikan lele pada perlakukan bobot 3, 4 dan $5 \mathrm{~kg} /$ ember serta frekuensi pemberian pakan satu dan dua kali per hari tidak berbeda nyata. Kepadatan ikan lele tertinggi $5 \mathrm{~kg} / \mathrm{ember}$ dengan frekuensi pemberian pakan satu kali sehari lebih direkomendasikan untuk memelihara dan menyimpan ikan di daerah sempit, sulit air dan daerah pasca bencana.

Tabel 1. Perbandingan Parameter antar Media Akuaponik

\begin{tabular}{|c|c|c|c|c|}
\hline \multirow[b]{2}{*}{ Parameter } & \multicolumn{4}{|c|}{ Aquaponik } \\
\hline & $\begin{array}{l}\text { Kulkas } \\
\text { Hidup }\end{array}$ & $\begin{array}{c}\text { Media-based } \\
\text { Grow Bed } \\
(\mathrm{MGB})\end{array}$ & $\begin{array}{c}\text { Deep-Water } \\
\text { System (DWC) }\end{array}$ & $\begin{array}{l}\text { Nutrient Film } \\
\text { Technique } \\
\text { (NFT) }\end{array}$ \\
\hline Volume Air $\left(\mathrm{m}^{3}\right)$ & $<1$ & - & 43 & $>38$ \\
\hline Sistem & Tergenang & Resirkulasi & Resirkulasi & Resirkulasi \\
\hline Kebutuhan Listrik & Tidak Butuh & Butuh Listrik & Butuh Listrik & Butuh Listrik \\
\hline Kebutuhan Lahan $\left(\mathrm{m}^{2}\right)$ & $<1$ & - & 220 & 498 \\
\hline Biaya Investasi / $\mathrm{m}^{2}(\$)$ & $<10$ & - & - & $\$ 201$ \\
\hline Skala Produksi & Rumahan & Usaha & Usaha & Usaha \\
\hline Jenis Ikan & $\begin{array}{l}\text { Ikan Lele } \\
\text { (Clarias } \\
\text { gariepinus) }\end{array}$ & - & $\begin{array}{l}\text { Ikan Nila } \\
\text { (Oreochromis } \\
\text { niloticus L.) }\end{array}$ & $\begin{array}{l}\text { Ikan Rainbow } \\
\text { Trout } \\
\text { (Oncorchynus } \\
\text { mykiss) }\end{array}$ \\
\hline Kepadatan Ikan & 71,4 & - & $61,5-70,7$ & 113,4 \\
\hline
\end{tabular}

Pemberian pakan satu kali per hari akan menghemat biaya pakan yang dikeluarkan, serta tidak terlalu repot dalam pemeliharaannya. Nilai FCR ikan lele dipengaruhi oleh faktor umur, kepadatan, genetika dan lingkungan. Secara berturut-turut FCR yang didapat pada perlakuan A, B dan C adalah sebagai berikut A $(0,47$ dan 1,05), B (0,81 dan 0,92) dan C (0,98 dan 1,09). Menurut Mardhiana dkk 
(2017) FCR ikan lele yang diberikan perlakuan penambahan probiotik pada pakan berkisar antara 1,72,0 .

Perbandingan parameter dari media akuaponik kulkas hidup dibandingkan dengan jenis akuaponik lain terlihat pada Tabel 1. Berdasarkan Tabel 1. Diketahui bahwa sistem akuaponik kulkas hidup mempunyai kelebihan antara lain:

a. Hemat air, karena volume air yang digunakan adalah hanya 70 liter

b. Sistemnya sederhana tidak menggunakan resirkulasi

c. Tidak butuh listrik

d. Dapat diterapkan di tempat / lahan sempit karena luas medianya hanya $0,785 \mathrm{~m} 2$

e. Biaya investasi lebih murah, sehingga dapat lebih aplikatif pada masyarakat

f. Akuaponik kulkas hidup mudah di laksanakan dan aplikatif untuk dilakukan pada skala rumah tangga

g. Jenis ikan masih terbatas pada ikan yang tidak butuh oksigen tinggi (hanya ikan yang mempunyai organ pernafasan tambahan)

h. Kepadatan ikan cukup tinggi yaitu $71,4 \mathrm{~kg}$ ikan dalam $1 \mathrm{~m}^{3}$

Sistem akuaponik budidaya ikan dalam ember, dengan memelihara ikan yang sudah berukuran besar secara harfiah berfungsi sebagai "Kulkas hidup", yaitu memelihara ikan dan sayuran dalam wadah ember, sekaligus juga berfungsi menjadi sarana untuk menyimpan ikan dan sayuran dalam keadaan hidup. Sistem tersebut menjadi sangat penting penerapannya untuk kebutuhan pangan di daerah sempit, daerah sulit air dan daerah pasca bencana.

Tabel 2. Perbandingan parameter produksi sayuran antar media akuaponik

\begin{tabular}{|c|c|c|c|c|}
\hline \multirow[b]{2}{*}{ Parameter } & \multicolumn{4}{|c|}{ Aquaponik } \\
\hline & Kulkas Hidup & $\begin{array}{l}\text { Media-based } \\
\text { Grow Bed } \\
(\mathrm{MGB})\end{array}$ & $\begin{array}{c}\text { Deep-Water } \\
\text { System (DWC) }\end{array}$ & $\begin{array}{l}\text { Nutrient Film } \\
\text { Technique } \\
\text { (NFT) }\end{array}$ \\
\hline Jenis Tanaman & $\begin{array}{l}\text { Tanaman } \\
\text { Kangkung } \\
\text { (Ipomea } \\
\text { aquatic) }\end{array}$ & - & $\begin{array}{l}\text { Tanaman Basil } \\
\text { (Ocimum } \\
\text { basicilum), Okra } \\
\text { (Abelmoschus } \\
\text { esculentus) }\end{array}$ & $\begin{array}{l}\text { Tanaman Basil } \\
\text { (Ocimum } \\
\text { basicilum), } \\
\text { Selada (Lactuca } \\
\text { sativa L) }\end{array}$ \\
\hline Media Tanam & Arang Kayu & $\begin{array}{l}\text { Batu tanah liat, } \\
\text { perlite, batu } \\
\text { apung, kerikil }\end{array}$ & $\begin{array}{l}\text { Rock wol, } \\
\text { cocopeat atau batu } \\
\text { apung }\end{array}$ & $\begin{array}{l}\text { Akar langsung } \\
\text { terendam air } \\
\text { (tanpa media) }\end{array}$ \\
\hline 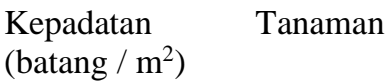 & $\begin{array}{l}50-100 \text { batang } \\
\text { (kangkung) }\end{array}$ & - & $\begin{array}{l}8 \text { (kemangi) } \\
2-4 \text { (okra) }\end{array}$ & $\begin{array}{l}5,7 \text { / meter baki } \\
\text { NFT }\end{array}$ \\
\hline $\begin{array}{l}\text { Pakan / hari / area tumbuh } \\
\text { tanaman area }\left(\mathrm{g} / \text { hari } / \mathrm{m}^{2}\right)\end{array}$ & $\begin{array}{l}57.9(1 \times \text { pakan }) \\
58.9(2 \times \text { pakan })\end{array}$ & - & 81.4-99.6 & \\
\hline
\end{tabular}

Perbandingan Parameter produksi sayuran antar Media Akuaponik. Parameter produksi sayuran antara media akuaponik kulkas hidup dibandingkan dengan jenis akuaponik lain terlihat pada Tabel 2. Sayuran kangkung pada media akuaponik kulkas hidup akarnya dapat terendam pada air yang kandungan oksigen relatif rendah dan kekeruhan yang tinggi. Jika dibandingan dengan model akuaponik lain kelebihan akuaponik kulkas hidup adalah:

a. Media tanam cukup dengan arang kayu, murah dan cukup mudah dicari

b. Kepadatan tanaman kangkung cukup tinggi sehingga dapat menghasilkan biomassa panen yang tinggi.

c. Perbandingan pakan / hari /area tumbuh tanaman cukup rendah, pemberian pakan yang rendah sudah mampu menghasilkan kangkung yang lebih banyak.

d. Pangan berupa ikan dan sayuran juga sangat dibutuhkan untuk daerah pasca bencana. Daerah pasca bencana dengan kondisi yang belum stabil umumnya masih mendapatkan pasokan pangan dari luar dan belum bisa menghasilkan secara mandiri secara cepat. Sistem budidaya 
Nursandi dan Aprilia : Sistem Akuaponik “Kulkas Hidup” Untuk Daerah Lahan Terbatas, Sulit Air...

ikan dan sayuran secara akuaponik menjadi penting untuk diterapkan karena selain dapat menjaga ketahanan pangan di daerah pasca bencana juga bisa menjadi pola pendidikan pembelajaran untuk masyarakat yang bernilai positif untuk pemulihan kondisi pasca bencana.

Kualitas Air. Hasil pengamatan kualitas air selama 42 hari terlihat pada Tabel 3. Hasil pengukuran suhu yang diperoleh selama penelitian adalah $23-32{ }^{\circ} \mathrm{C}$. Suhu setiap media akuaponik kulkas hidup sama pada setiap ember. Suhu air berbeda antar waktu pengamatan, terjadi fluktuasi suhu di media karena ember diletakkan di lokasi terbuka (outdoor) yang dipengaruhi suhu lingkungan baik hujan maupun panas dari matahari.

Tabel 3. Hasil Pengamatan Kualitas Air

\begin{tabular}{llll}
\hline No & \multicolumn{1}{c}{ Parameter } & \multicolumn{1}{c}{ Hasil pengukuran } & \multicolumn{1}{c}{ Pustaka } \\
\hline 1. & Suhu & $23-32^{\circ} \mathrm{C}$ & $25,0-31,5^{\circ} \mathrm{C}$ (Elpawati, 2015) \\
2. & Oksigen Terlarut (DO) & $2-6 \mathrm{ppm}$ & $>5 \mathrm{mg} / \mathrm{L}(\mathrm{BSN}, 2000)$ \\
3. & $\mathrm{pH}$ & $5,21-7,05$ & $6,5-8$ (Elpawati, 2015) \\
4. & $\mathrm{NH}_{3} / \mathrm{NH}_{4}$ & $0-5 \mathrm{ppm}$ & $0,1 \mathrm{mg} / \mathrm{L}$ (Ghufron \& Kordi, 2010) \\
\hline
\end{tabular}

Hasil pengukuran ini menunjukkan bahwa suhu air media budikdamber selama penelitian masih sesuai dengan kebutuhan hidup ikan lele sangkuriang yakni $25,0-31,5^{\circ} \mathrm{C}$ (Elpawati, 2015). Kandungan DO pada media budikdamber adalah $2-6 \mathrm{mg} / \mathrm{L}$. Kandungan oksigen yang kecil dari $4 \mathrm{mg} / \mathrm{L}$ dapat saja menjadi faktor penyebab kematian ikan. DO yang rendah dapat menjadi penyebab dari ikan lele yang menggantung di permukaan air pada waktu-waktu tertentu. Ikan akan saling berkompetisi dengan ikan yang lain untuk melakukan respirasi.

Hasil pengukuran $\mathrm{pH}$ selama penelitian adalah 5,21-7.05. Hasil pengukuran ini menunjukan bahwa $\mathrm{pH}$ air budikdamber dalam kondisi yang masih bisa ditoleransi oleh ikan lele. Menurut Elpawati (2015), ikan lele hidup baik dalam pH kisaran 6.5-8. Keasaman yang terlalu rendah dapat menyebabkan ikan stress, mudah terserang penyakit, produktivitas dan pertumbuhan rendah.

Hasil pengukuran total amoniak $\mathrm{NH}_{3}$ dan $\mathrm{NH}_{4}$ yang diperoleh selama penelitian berlangsung berkisar 0 - $5 \mathrm{mg} / \mathrm{L}$. Hasil pengukuran ini menunjukkan fluktuasi kadar amoniak yaitu tinggi pada saat malam hari dan rendah kembali saat siang hari. Kadar ammonia dalam media budikdamber diduga naik bila ikan diberi pakan yang berlebihan. Batas optimum kandungan khusus untuk ammonia $\mathrm{NH}_{3}$ untuk pertumbuhan ikan lele yaitu $0.1 \mathrm{mg} / \mathrm{L}$ (Ghufron \& Kordi, 2010).

\section{KESIMPULAN}

Akuaponik Sistem kulkas hidup ikan lele di media ember 80 liter dapat dijadikan model untuk memelihara dan menyimpan ikan serta sayuran pada daerah padat / lahan yang sempit, daerah sulit air dan daerah pasca bencana.

\section{DAFTAR PUSTAKA}

BSN. (2000). Benih Ikan Lele Dumbo (Clarias gariepinus x C. Fuscus) Kelas Benih Sebar. SNI : 01 6484.2-2000

Chakravartty, D., Mondal, A., Raychowdhury, P., Bhattacharya, S. B., \& Mitra, A. (2017). Role of aquaponics in the sustenance of coastal India -. International Journal of Fisheries and Aquatic Studies, 441-448.

Effendie, M. I. (1997). Biologi Perikanan. Yayasan Pustaka Nusatama. Yogyakarta. 
Elpawati, Pratiwi, D. R., Radiastuti, N. (2015). Aplikasi Effective Microorganism 10 (EM10) Untuk Pertumbuhan Ikan Lele Sangkuriang (Clarias gariepinus var. Sangkuriang) Di kolam Budidaya Lele Jombang. Al-Kauniyah Jurnal Biologi Volume 8 (1). UIN Syarif Hidayatullah Jakarta

Forchinoa, A. A., Gennotte, V., Maiolo, S., Mélard, C., \& Pastres, R. (2018, April - May). Eco-designing Aquaponics: a case study of an experimental production. ScienceDirect, 546 - 550. doi:DOI: 10.1016/j.procir.2017.11.064

Goddard S. 1996. Feed Management in Intensive Aquaculture. Chapman and Hall. New York. hlm 194.

Gosh, K., \& Chowdhury, S. (2019, March). Review of Aquaponics System: Searching for a Technically. Journal ofAgricultural, Environmental and Consumer Sciences - Vol. 19, Vol. 19, 5-13.

Ghufran, H., Kordi, M. (2010). Budidaya Ikan Lele Di Kolam Terpal. Lily Publisher. Yogyakarta

Huisman, E. A. (1987). The Principles of Fish Culture Production. Department of Aquaculture, Wageningen University, The Netherland. hlm 100.

Kesuma B., W., Budiyanto, Brata B., (2019). Efektivitas Pemberian Probiotik dalam Pakan terhadap Kualitas Air dan Laju Pertumbuhan pada Pemeliharaan Lele Sangkuriang (Clarias gariepinus) Sistem Terpal. Naturalis Jurnal Penelitian Pengelolaan Sumberdaya Alam dan Lingkungan. EISSN: 2654-7732

Nursandi, J. (2018). Budidaya Ikan Dalam Ember "Budikdamber" dengan Akuaponik di Lahan Sempit. Prosiding Seminar Nasional Pengembangan Teknologi Pertanian. ISBN 978-602-5730-68-9, pp. 129-136. Bandar Lampung: Politeknik Negeri Lampung. Retrieved from http://jurnal.polinela.ac.id/index.php/PROSIDING

Palm, H. W., Knaus, U., Appelbaum, S., Goddek, S., Strauch, S. M., Vermeulen, T., . . Kotzen, B. (2018). Towards commercial aquaponics: a review of systems,. Aquacult Int. Retrieved from https://doi.org/10.1007/s10499-018-0249-z

Rokhmah, N. A. , Ammatillah, C. A., dan Sastro, Y. (2014).Vertiminaponik, Mini Akuaponik untuk Lahan Sempit di Perkotaan. Buletin Pertanian Perkotaan Volume 4 Nomor 2,

Wongkiew, S., Hu, Z., Chandran, K., Lee, J. W., \& Khanal, S. K. (2017). Nitrogen transformations in aquaponic systems: A review. Aquacultural Engineering, 9-19. Retrieved from www.elsevier.com/locate/aqua-online

Wicaksana, S. N., Hastuti, S., Arini, E. (2015). Performa Produksi Ikan Lele Dumbo (Clarias gariepinus) yang dipelihara dengan Sistem Biofilter Akuaponik dan Konvensional. Journal of Aquaculture Management and Technology Volume 4, Nomor 4. Halaman 109-116. Fakultas Perikanan dan Ilmu Kelautan, Universitas Diponegoro.

Wiwaha, A. A., Gunanda A. D., Krisnawati R. (2018). Strategi Recovery Sektor Pertanian Pascabencana Gempa di Kabupaten Lombok Utara. Jurnal Dialog Penanggulangan Bencana. BNPB. Volume 9, Nomor 2. Hal. 89 - 182. 